\title{
SERIAL ECHOCARDIOGRAPHIC ASSESSMENT OF VENTRICULAR FUNCTION USING TISSUE DOPPLER IMAGING IN VERY LOW BIRTHWEIGHT INFANTS WITHIN FIRST 7 DAYS OF LIFE
}

\author{
M. Murase ${ }^{1}$, T. Morisawa ${ }^{2}$, A. Ishida ${ }^{3}$ \\ ${ }^{1}$ Mitsu Municipal Hospital, Hyogo, ${ }^{2}$ Kakogawa Municipal Hospital, Kakogawa, ${ }^{3}$ Kobe Children's First-aid \\ Center, Kobe, Japan
}

Background and aims: We aimed to evaluate early changes of ventricular function in very low birthweight(VLBW) infants using tissue Doppler imaging(TDI) echocardiography.

Methods: Consecutive assessment of echocardiography from $3 \mathrm{~h}$ to days 7 was performed for 102 VLBW infants weighing less than $1500 \mathrm{~g}$, who were admitted to Kakogawa Municipal Hospital between September 2004 and August 2007. TDI was assessed at a lateral annulus both of mitral valve(MV) and tricuspid valve(TV). Peak annular velocities in systole(Sa), early diastole(Ea), and late diastole(Aa) were measured both on MV and TV.

Results: Mean gestational age of patients was 28.2 weeks (21.0-33.9), and mean birthweight was $1057 \mathrm{~g}$ (360-1496). Trans mitral(MV) Sa fell down significantly from $3 \mathrm{~h}$ to $24 \mathrm{~h}(\mathrm{p}<0.0001)$, then remained to a steady level of $4 \mathrm{~cm} / \mathrm{second}$. There was no significant change in time-course of MV Ea within 7 days $(4.1 \pm 1.0 \mathrm{~cm} / \mathrm{second})$, but values of Ea in premature group were significantly lower than those in more mature group $(\mathrm{p}<0.01)$ before $12 \mathrm{~h}$ of life. Left ventricular E/Ea appeared to keep a steady level of 7.1 \pm 2.7 , regardless of postnatal hours or their gestational age. Trans tricuspid(TV) Sa also fell down significantly from $3 \mathrm{~h}$ to $12 \mathrm{~h}(\mathrm{p}<0.001)$, then kept a constant value (around $5 \mathrm{~cm} / \mathrm{second}$ ). Values of TV Ea appeared to decrease gradually from $3 \mathrm{~h}$ to days $7(\mathrm{p}<0.0001)$. Right ventricular $\mathrm{E} / \mathrm{Ea}$ also showed no significant change throughout the early neonatal period $(7.9 \pm 2.8)$.

Conclusions: In very premature infants, TDI velocities may reflect both systolic and diastolic ventricular function in the early neonatal period. 